http://dx.doi.org/10.11646/phytotaxa.155.1.5

\title{
Two new species of Trachyandra sect. Liriothamnus (Xanthorrhoeaceae, Asphodeloideae) from the Western and Eastern Cape Provinces of South Africa
}

\author{
JAMES STEPHEN BOATWRIGHT ${ }^{1 *} \&$ JOHN CHARLES MANNING ${ }^{2,3}$ \\ ${ }^{l}$ Department of Biodiversity and Conservation Biology, University of the Western Cape, Private Bag x17, Bellville, 7535, Cape Town, \\ South Africa; e-mail: jboatwright@uwc.ac.za \\ ${ }^{2}$ Compton Herbarium, South African National Biodiversity Institute, Private Bag X7, Claremont, 7735, Cape Town, South Africa; \\ e-mail: J.Manning@sanbi.org.za \\ ${ }^{3}$ Research Centre for Plant Growth and Development, School of Life Sciences, University of KwaZulu-Natal, Pietermaritzburg, Private \\ Bag x01, Scottsville 3209, South Africa. \\ *Author for correspondence
}

\begin{abstract}
Trachyandra eriocarpa and T. bulbosa are two new species from Northern and Eastern Cape Provinces of South Africa. They are placed in $T$. sect. Liriothamnus based on their wiry roots, the cataphylls not forming membranous collars, and the remains of the outer leaves forming a fibrous collar. Trachyandra eriocarpa from the Great Winterberg in Eastern Cape is recognised by its unusual, villous ovary and capsules; and T. bulbosa from north of Springbok in Northern Cape by the irregular, bulbous rhizome, microscopically puberulous leaves and maculate tepals.
\end{abstract}

Key words: Asphodeloideae, new species, South Africa, taxonomy, Trachyandra

\section{Introduction}

The genus Trachyandra Kunth (1843: 573) (Xanthorrhoeaceae: Asphodeloideae) currently comprises ca. 55 species in Africa and Madagascar, with the majority of species concentrated in the Greater Cape Floristic Region (Obermeyer 1962; Boatwright \& Manning 2010), where some 42 species are found (Manning \& Goldblatt 2012; Snijman 2013).

Phylogenetic relationships within and among certain genera of Asphodeloideae are poorly understood and are the subject of ongoing taxonomic and molecular studies, during which several new species have come to light (Boatwright \& Manning 2010; J.S. Boatwright et al. in prep.). Here we describe a further two, distinctive species of T. section Liriothamnus (Schlechter 1924: 145) Obermeyer (1962: 720). This section, which currently comprises 13 species, is characterised by wiry, unthickened roots; the lowest, entirely sheathing leaves or cataphylls (prophylls in the sense of Obermeyer 1962) not forming a membranous collar ('squamae' in the sense of Obermeyer 1962); and the remains of the leaf bases persisting around the base of the stem as a fibrous collar (Obermeyer 1962). Inflorescences are mostly simple and the perianth in most of the species is immaculate. Sections Glanduliferae Obermeyer (1962: 751) and Trachyandra have mostly branched inflorescences and often maculate tepals. Section Glanduliferae is diagnosed by the glandular-pubescence, at least on the ovary, and sect. Trachyandra by the \pm swollen roots, often fused into fleshy tubers, and the cataphylls transformed into membranous, collar-like sheaths that surround the stem and individual leaf bases (Obermeyer, 1962). This sectional classification, however, remains to be tested. 


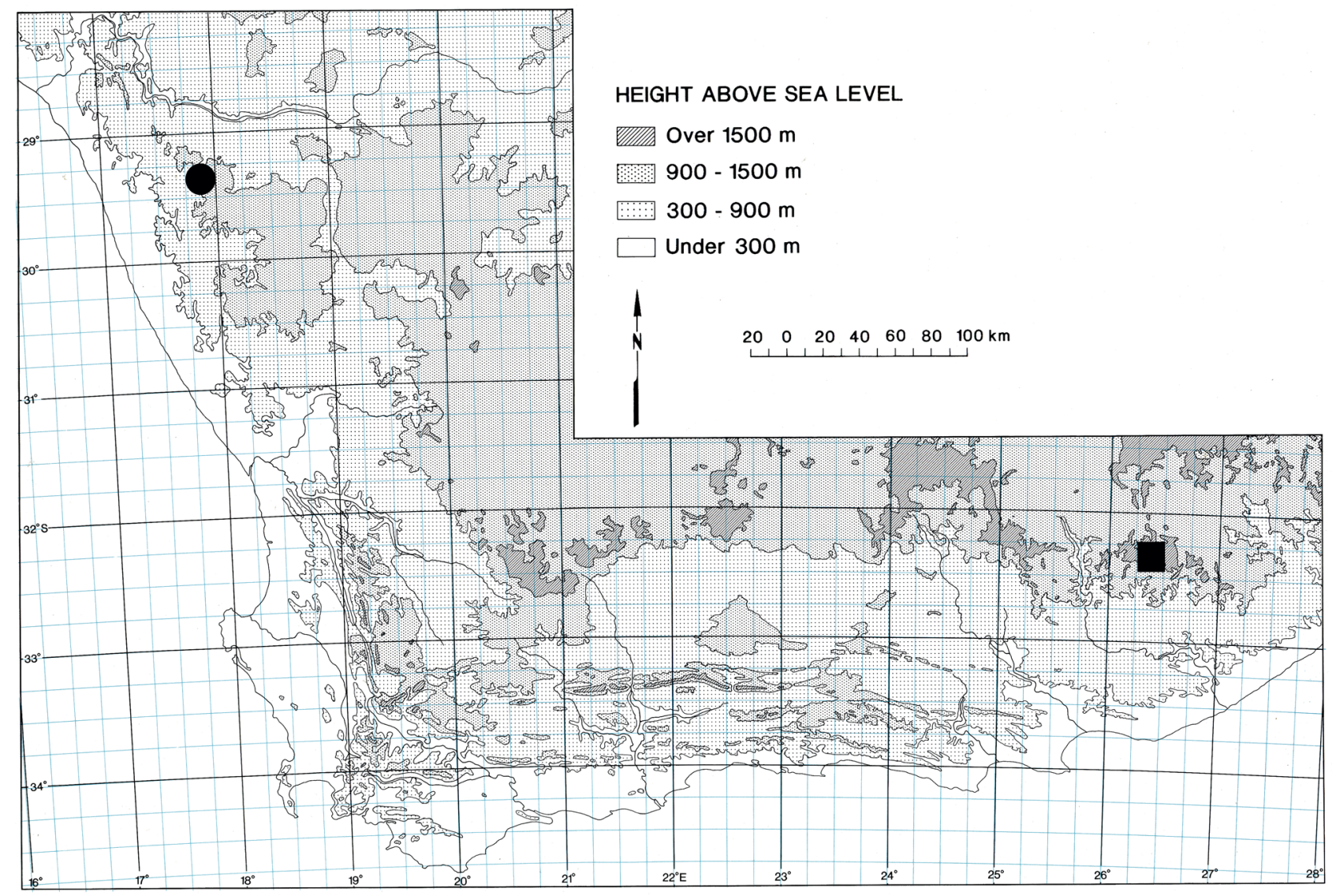

FIGURE 3. Known geographical distribution of Trachyandra eriocarpa (square) and T. bulbosa (circle).

\section{Acknowledgements}

Funding from the South African Biosystematics Initiative (SABI) and the National Research Foundation of South African is gratefully acknowledged. We also thank the Curator of GRA for the specimen received on loan.

\section{References}

Baker J.G. (1876) Revision of the genera and species of Anthericeae and Eriospermae. Journal of the Linnean Society 15: 253-363. http://dx.doi.org/10.1111/j.1095-8339.1876.tb00247.x

Boatwright, J.S. \& Manning, J.C. (2010) Notes on the genus Trachyandra (Asphodelaceae: Asphodeloideae) 1: a review of the T. thyrsoidea group (Section Trachyandra), including three new species from the Northern Cape. South African Journal of Botany 76: 499-510. http://dx.doi.org/10.1016/j.sajb.2010.03.007

Compton, R.H. (1931) Novitates Africanae. Journal of Botany, British and Foreign 69: 10-11.

Edwards, D. \& Leistner, O.A. (1971) A degree reference system for citing biological records in southern Africa. Mitteilungen des Botanische Staatssammlung München 10: 501-509.

Kunth, C.S. (1843) Enumeratio plantarum omnium hucusque cognitarum: secundum familias naturales disposita, adjectis characteribus, differentiis et synonymis 4. J.G. Cottae, Stuttgart, 752 pp. http://dx.doi.org/10.5962/bhl.title.67381

Kuntze, O. (1898) Revisio generum plantarum 3, 2. Arthur Felix, Leipzig, 576 pp.

Leistner, O.A. \& Morris, J.W. (1976) South African place names. Annals of the Cape Provincial Museums 12: 1-565.

Manning, J.C. (1990) A new species of Trachyandra section Liriothamnus (Asphodelaceae) from the Richtersveld. South 
African Journal of Botany 56: 1-5.

http://dx.doi.org/10.1016/j.sajb.2010.03.007

Manning, J.C. \& Goldblatt, P. (2012) Plants of the Greater Cape Floristic Region 1: The Core Cape Flora. Strelitzia 29. South African National Biodiversity Institute, Pretoria, $853 \mathrm{pp}$.

Mucina, L., Jürgens, N., le Roux, A., Rutherford, M.C., Schmiedel, U., Essler, K.J., Powrie, L.W., Desmet, P.G. \& Milton, S.J. (2006) Succulent Karoo Biome. In: Mucina, L. \& Rutherford, M.C. (eds.) The Vegetation of South Africa, Lesotho and Swaziland. Strelitzia 19. South African National Biodiversity Institute, Pretoria, pp. $221-299$.

Obermeyer, A.A. (1962) A revision of the South African species of Anthericum, Chlorophytum and Trachyandra. Bothalia 7: 669-767.

Schlechter, R. (1924) Drei neue Gattungen der Liliaceen aus Südafrika. Notizblatt des Botanischen Gartens und Museums zu Berlin-Dahlem 9: 145-151. http://dx.doi.org/10.2307/3994398

Snijman, D.A. (2013) Plants of the Greater Cape Floristic Region 2: The Extra Cape Core Flora. Strelitzia 30. South African National Biodiversity Institute, Pretoria, $542 \mathrm{pp}$.

Thiers, B. (2011) Index Herbariorum: A global directory of public herbaria and associated staff. New York Botanical Garden's Virtual Herbarium. Available from http://sweetgum.nybg.org/ih/ (accessed: 20 November 2013). 